\title{
A LEADING INDICATOR FOR THE DUTCH ECONOMY - METHODOLOGICAL AND EMPIRICAL REVISION OF THE CPB SYSTEM
}

\author{
HENK C. KRANENDONK \\ JAN BONENKAMP \\ JOHAN P. VERBRUGGEN
}

\author{
CESIFO WORKING PAPER NO. 1200 \\ CATEgORY 5: Fiscal Policy, Macroeconomics AND GROWTH \\ MAY 2004
}

PReSENTED AT CESifo CONFERENCE “ACADEMIC USE OF Ifo SURVEy DATA" DECEMBER 2003

\footnotetext{
An electronic version of the paper may be downloaded

- from the SSRN website: www.SSRN.com

- from the CESifo website: www.CESifo.de
} 


\title{
A LEADING INDICATOR FOR THE DUTCH ECONOMY - METHODOLOGICAL AND EMPIRICAL REVISION OF THE CPB SYSTEM
}

\begin{abstract}
Since 1990 the Netherlands Bureau for Economic Policy Analysis (CPB) uses a leading indicator in preparing short-term forecasts for the Dutch economy. This paper describes some recent methodological innovations as well as the current structure and empirical results of the revised CPB leading indicator. Special attention is paid to the role and significance of IFO data. The structure of the CPB leading indicator is tailored to its use as a supplement to model-based projections, and thus has a unique character in several respects. The system of the CPB leading indicator is composed of ten separate composite indicators, seven for expenditure categories ('demand') and three for the main production sectors ('supply'). This system approach has important advantages over the usual structure, in which the basis series are directly linked to a single reference series. The revised system, which uses 25 different basic series, performs quite well in describing the economic cycle of GDP, in indicating the upturns and downturns, and in telling the story behind the business cycle.
\end{abstract}

JEL classification: E37.

Keywords: leading indicator, short-term forecasts.

\author{
Henk C. Kranendonk \\ CPB Netherlands Bureau for Economic \\ Policy Analysis \\ P.O. Box 80510 \\ 2508 GM The Hague \\ The Netherlands \\ h.c.kranendonk@cpb.nl
}

\author{
Jan Bonenkamp \\ CPB Netherlands Bureau for Economic \\ Policy Analysis \\ P.O. Box 80510 \\ 2508 GM The Hague \\ The Netherlands \\ janbonenkamp@hotmail.com
}

\author{
Johan P. Verbruggen \\ PB Netherlands Bureau for Economic Policy \\ Analysis \\ P.O. Box 80510 \\ 2508 GM The Hague \\ The Netherlands \\ j.p.verbruggen@cpb.nl
}

We would like to thank Gerard Ronning for his valuable remarks on the draft version of this paper. 


\section{$1 \quad$ Introduction}

The large-scale econometric quarterly model SAFE plays a key role in the short-term projections for the Dutch economy prepared by the Netherlands Bureau for Economic Policy Analysis (CPB). ${ }^{2}$ Since 1990 the CPB also uses a leading indicator for the Dutch economy, the so-called CPB leading indicator. ${ }^{3}$ Since that time the quarterly reports on the projections for the economy also refer to the signal given by this indicator. The CPB leading indicator consists of two elements. The 'realisation' is meant to describe the actual development of GDP-growth in the Netherlands. The 'indicator' summarizes all the available information of leading time series and is designed to give an indication of GDP in the near future and to signal turning points in advance. $^{4}$

The structure of the CPB leading indicator is tailored to its use as a supplement to modelbased projections, and has a unique character in several respects. Thus gross domestic product (GDP) is used as the reference series, and the system of the CPB leading indicator is composed of ten separate composite indicators, seven for expenditure categories ('demand') and three for the main production sectors ('supply'). A detailed study was conducted recently into the methods and techniques used. Particular attention was paid to the way in which time series are adjusted for their trend-based development and to the way in which the cyclical dynamics of a series can best be calculated. ${ }^{5}$ Public spending was also included in the system as a separate

\footnotetext{
${ }^{2}$ See CPB (2003) for a description of the SAFE model.

${ }^{3}$ See Kranendonk (1990).

${ }^{4}$ In this article the terms CPB leading indicator and composite indicator are used as synonyms.

${ }^{5}$ See Bonenkamp (2003).
} 
expenditure category. And finally, all existing and potential new basic series were again tested for their predictive abilities. This has led to a situation where the CPB leading indicator now uses 25 different basic series, including two series from the German IFO Institute. This CPB leading indicator has a lead of three or four months. From the 25 series we selected 7 series which have a lead of at least nine months. These are aggregated to the 'long-leading' indicator, which has therefore a lead of three quarters to the reference series.

This article is structured as follows. Section 2 examines the methodological innovations and the current structure of the CPB leading indicator. Section 3 considers the empirical results of the construction and pays particular attention to the role and significance of IFO data. The performance of the CPB leading indicator and its components is discussed in section 4. Finally section 5 explains how the indicator is used in the preparation of the CPB's short-term projections.

\section{$2 \quad$ Methodology and structure}

\subsection{Choice of reference series}

The CPB's methodology, which is based on the widely applied NBER methodology, uses socalled 'deviation cycles'. ${ }^{6}$ Deviation cycles regard cyclical movements as fluctuations around a permanent trend component. The first step is choosing a reference series which offers an appropriate reflection of economic activity. Manufacturing output is often used for this. The CPB leading indicator is the only Dutch economic indicator which uses GDP as the reference series. $^{7}$

\footnotetext{
${ }^{6}$ See e.g. Burns and Mitchell (1946) and OECD (1987).
}

\footnotetext{
${ }^{7}$ There are two other leading indicators for the Netherlands. The Dutch Central Bank uses manufacturing production as reference series and has selected five series (see Den Reijer, 2002). The Rabobank uses a composite index of five series for the description of the business cycle. Their leading indicator consists of five other series (see Assenbergh, 2000).
} 
On the assumption that the purpose of an economic indicator is to give an impression of overall economic developments in the future, GDP is in principle a more suitable reference series than manufacturing output. After all, manufacturing output accounts for only $15 \%$ of Dutch GDP, while the services sector accounts for 50\% of GDP. Although it must be said that the small share of manufacturing output need not as such be a reason for disqualification in this regard. For if the industrial sector is broadly as dynamic as the services sector, then the small share of manufacturing in the total economy is not a problem. Moreover, GDP has a practical disadvantage in that the actual figures only become available on a quarterly basis, whereas manufacturing output figures are published every month.

Figure 2.1 shows the economic cycles of manufacturing output and GDP for the years between 1975 and 2001. It also shows the performance of the services sector.

\section{Figure 2.1 Economic cycles of GDP and the production of manufacturing industry and the services sector in the Netherlands 1}

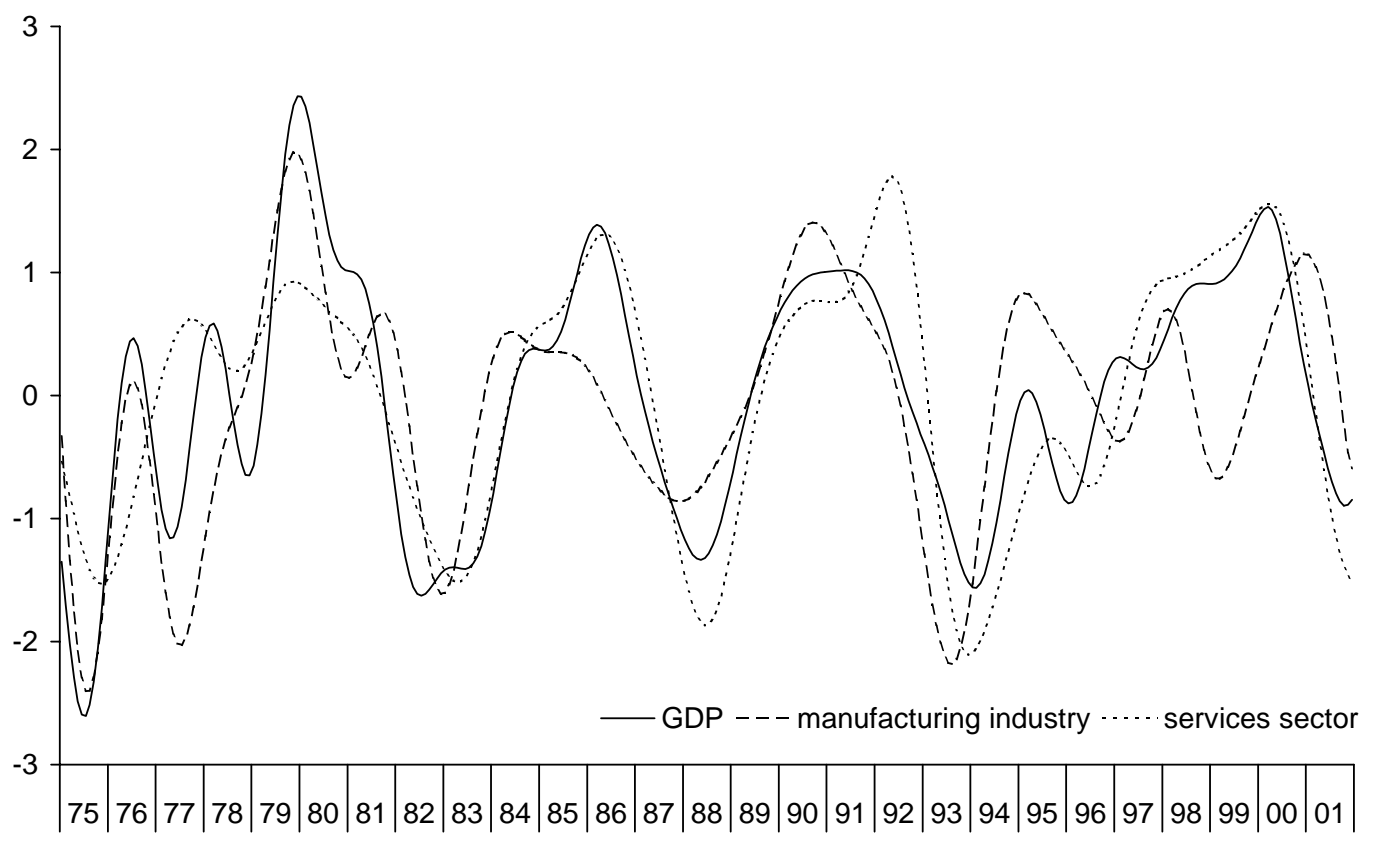

\footnotetext{
${ }^{1}$ The series have been filtered with the band pass filter of Christiano and Fitzgerald. The selected bandwidth is 18-120 months.
} 
At a value of 0.70 , the correlation coefficient between the manufacturing output and GDP series is quite high. During the period under consideration, manufacturing output had an additional peak and through during the second half of the 1990s. It is also worth noting that the turning points in manufacturing output occurred earlier than those for GDP, with the exception of the second half of the 1990s. Finally, the pattern of both series has varied sharply in recent years, as evident from a correlation coefficient of 0.17 between 1994 and 2001. Since 1994 GDP was determined to a large extent by the development of the services sector, which from that year deviated sharply from the performance of the industrial sector. Until 1994 the cyclical pattern of the manufacturing industry and the services sector were quite comparable. At most turning points, manufacturing industry is leading some months. After 1994 the resemblance is much lower, because manufacturing industry shows three cycles and the services sector only one.

In short, up to and including the first half of the 1990s the small share of manufacturing output in GDP is not a serious problem. Until then the industrial and services sectors broadly moved in tandem, so that the development of manufacturing output provided a representative picture of the total economy's performance. But this situation changed in the second half of the 1990s. During this time the services sector developed more or less independently of the industrial sector, so that the dynamism of manufacturing output no longer provided a reliable guide to the dynamism of the economy as a whole. Thus manufacturing output was no longer a reliable reference series.

\subsection{Filters and the end-point problem}

The elimination of trend-based components from the time series used is an important next step in the construction of an economic indicator based on deviation cycles. A serious drawback of the application of a filter is known as the 'end-point problem', i.e. which arises because the addition of new or revised observations changes the filtered values of previous observations. The end-point problem presents a serious handicap in the prediction of economic developments on the basis of leading series. In terms of the functionality of an indicator of economic activity, 
it is therefore very important to have an understanding of the sensitivity to new observations. This section examines, on the basis of empirical data, to what extent the sensitivity to new observations differs between filters. Three filters are compared, namely the Christiano and Fitzgerald (CF) filter, the Baxter and King (BK) filter and the Hodrick and Prescott (HP) filter.

The interpretation of the end-point problem differs from filter to filter. The HP filter calculates the trend component and identifies the cyclical component as the difference between the original series and the trend component. The end-point problem is therefore concentrated on changes in the trend component. This is different for the band pass filters, since these filters, given the standard decomposition of an economic time series in a trend-based, cyclical and disrupting component, calculate at least two components. The interpretation of the end-point problem is thus not restricted to a single component, as in the case of the HP filter. ${ }^{8}$

The fact that filtered observations change when new figures are added can lead on the one hand to changes in the intensity of the cyclical fluctuations at the end of the series, and on the other hand - and this is far more serious - to phase shifts. Depending on the type of filter, the endpoint problem has two causes. To prevent observations dropping off at the end of the series, it is usual to expand the routine of a symmetrical filter with an extrapolation method. However, if the filtered values depend in part on artificial observations, it is hardly surprising that the addition of actual observations can bring about changes. An asymmetrical filter calculates the trend component at the end of the series on the basis of 'the past'. Consequently the availability of new figures will inevitably also lead to changes.

\footnotetext{
${ }^{8}$ See Bonenkamp (2003).
} 
Filters

The Christiano and Fitzgerald (CF) filter and the Baxter and King (BK) filter are band pass filters. A band pass filter is a linear moving average which leaves cyclical fluctuations in tact while filtering out the high frequencies (month-to-month fluctuations) and low frequencies (underlying trend). The CF filter is an asymmetrical weighting scheme which uses all observations for the calculation of the filtered values. ${ }^{9}$ The BK filter, on the other hand, is a symmetrical filter with a constant weighting scheme. In contrast with an asymmetrical filter, a symmetrical filter has a moving average with the same number of leads and lags. The advantage of a symmetrical filter lies in the prevention of phase shifts in the filtered series. ${ }^{10}$ In contrast with the band pass filters, the Hodrick and Prescott (HP) filter only eliminates the low frequencies or long-term waves from a time series. The relationship between the variances of the trend component and the cyclical component, represented by the parameter $\lambda$, plays a key role in the HP filter. ${ }^{11}$ The parameter $\lambda$ determines the curve of the trend component. In case $\lambda=0$, there is no difference between the trend component and the original series. As $\lambda$ approaches infinity, the trend-based component begins to appear as a linear trend.

Figures 2.2 to 2.4 illustrate the end-point problem on the basis of the cyclical component of

Dutch exports. In each chart, one year (i.e. 12 monthly figures) is added systematically. The first month is December 1994 and the last month December 2001. In this case the HP filter has $\lambda=129600$, and the band pass filters have a bandwidth with 18 months as the lower limit and 120 months as the upper limit. These two input values are very comparable, so that differences in the sensitivity to the end values cannot be traced back to differences in the extent of filtering.

\footnotetext{
${ }^{9}$ See Christiano and Fitzgerald (2003).

${ }^{10}$ See Baxter and King (1999).

${ }^{11}$ See Hodrick and Prescott (1997).
} 
Figure 2.2 Cyclical component of exports - HP filter $(\lambda=129600)$

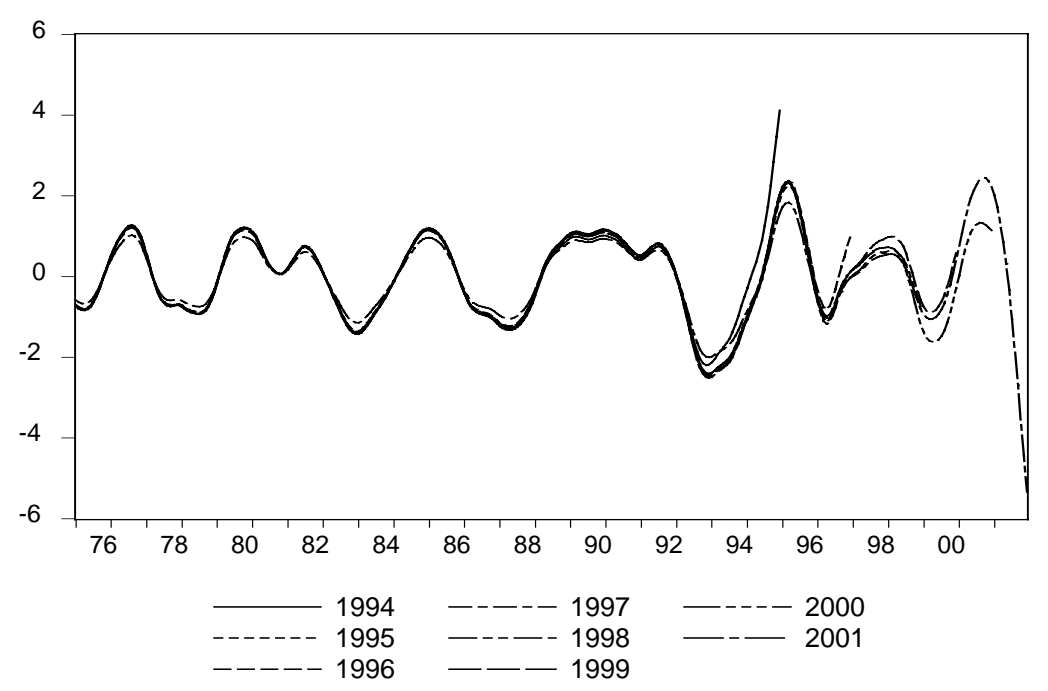

Figure 2.3 Cyclical component of exports - BK filter (bandwidth 18-120)

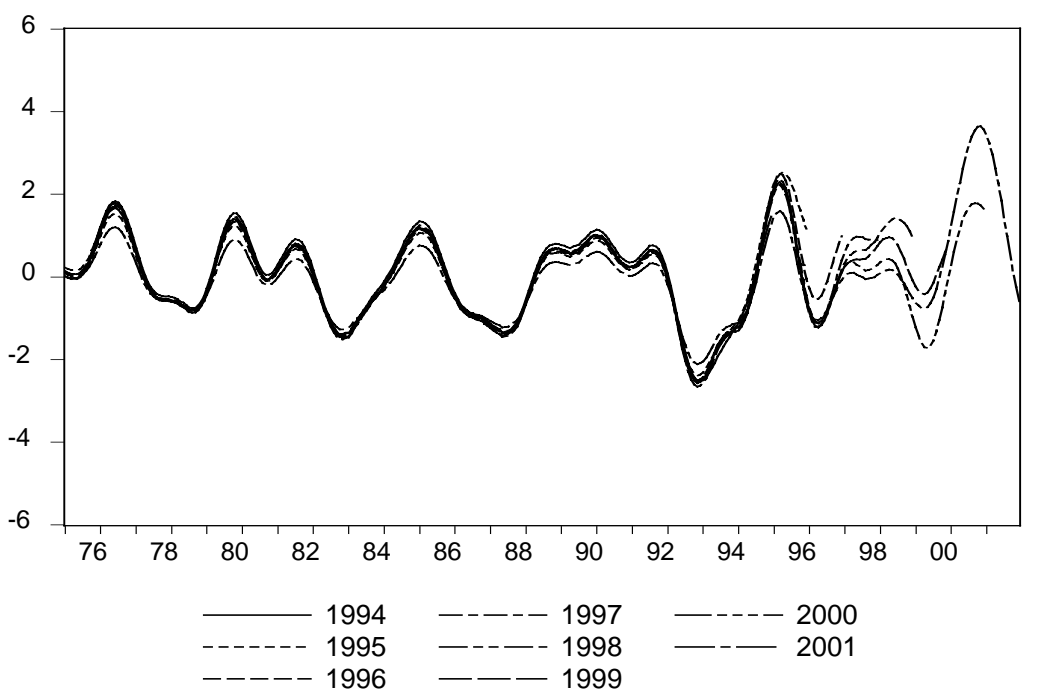




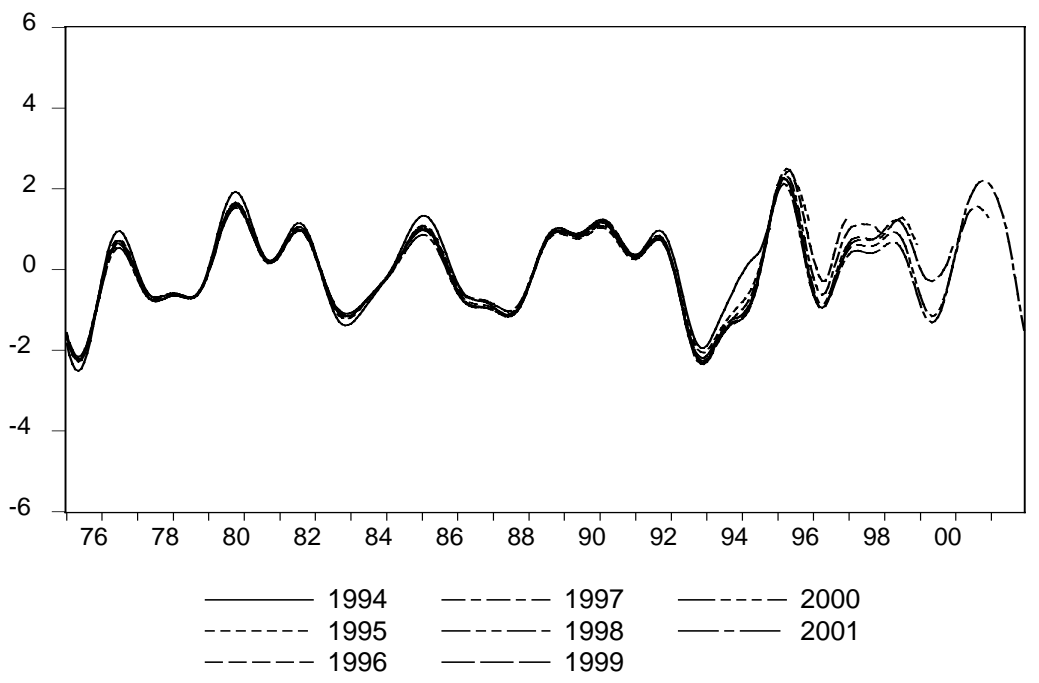

A comparison of figures 2.2 and 2.3 shows that, leaving aside the revisions arising from the addition of new observations, the three series move closely in line. This tallies with the general picture which emerges from the literature: no matter how different the filters in a technical and/or theoretical sense, the generated filtered series usually barely differ from each other. ${ }^{12}$ But there are some differences, caused by the addition of new observations. The HP-filtered series shows a spike when 1994 is the final year which is not evident to the same extent in the other two series and which eventually, following the addition of new observations, proves to be a false signal. Bearing this in mind, the downward spike in 2001 may reveal more about the inadequacies of the HP filter than about the actual economic situation. The two other series also show downward phases in 2001, but these are significantly gentler than in the HP series. This drawback of the HP filter has already been highlighted by Giorno et al. (1995). It seems that the trend which this HP filter generates is too heavily influenced by cyclical developments in the recent past. In comparison with the HP- and CF-filtered series, the spike in 2000 in the BK

${ }^{12}$ See e.g. Zarnowitz and Ozyildirim (2002), Chadha and Nolan (2002) and Agresti and Mojon (2001). 
series does not seem plausible. This may be related to the nature of the extrapolation method used in the BK filter.

This raises the question to what extent changes in the input values affect the end-point problem. For the HP filter this boils down to another value for $\lambda$, and for the band pass filters to another bandwidth. An increase in the value of $\lambda$ has the same effect as a wider bandwidth. De Haan and Vijselaar (1998) argue that a high value for $\lambda$ has a positive effect on the end-point problem. A higher $\lambda$ implies a less flexible trend component, so that this becomes less susceptible to the inappropriate introduction of cyclical fluctuations. However, a higher $\lambda$ or a wider bandwidth also has a downside. For there is a chance that a less flexible or too inflexible trend is not able to signal actual changes in that trend in time. This possibility is particularly likely in asymmetrical filters, because at the end of the series these filters are based exclusively on historical observations.

To gain a better understanding of the sensitivity of the three filters to the end-point problem, we carried out a formal sensitivity test, following Den Reijer (2002). We also examined to what extent a change in the input values plays a role. The selection of the input values followed on from the guidelines suggested in the literature. The CPB leading indicator uses monthly data. For the HP filter this meant, based on the work of Ravn and Uhlig (2002), a value of $\lambda=129600$. In line with the arguments and selection by De Haan and Vijselaar (1998), $\lambda=10^{6}$ was also included in the analysis. For the band pass filters this meant, based on Agresti and Mojon (2001), a bandwidth with a lower limit of 18 months and an upper limit of 120 months. Following Baxter and King (1999), a bandwidth with a lower limit of 18 months and an upper limit of 96 months was also used. The sensitivity of the filters to the addition of new observations was measured on the basis of 'revision errors' in the level of the cyclical component. That is to say, we examined to what extent a filtered observation at time t changes when a number of $\mathrm{n}$ year(s) of observations are added successively until $\mathrm{T}(\mathrm{T}>\mathrm{t})$. Absolute revision errors (RE) are calculated as follows: 


$$
R E_{n}=L I_{t t^{+n}}-L I_{t T}
$$

'LI' stands for 'leading indicator', and the symbols in this case have the following values: $t=1994: 12, T=2001: 12$ and $n=0,1, \ldots, 7$. Equation (1) determines to what extent a filtered value at time $\mathrm{t}$ (given data until $\mathrm{t}+\mathrm{n}$ ) deviates from its 'real' value (given data until $\mathrm{T}$ ). We assumed that a filtered value after seven years (which in the case of monthly figures means no fewer than 84 observations) will not change. Sixteen different time series were included in the analysis, such as GDP, the expenditure categories, manufacturing output, output in the services sector, the money supply, long-term interest rates and the IFO indicator. Table 2.1 shows the average outcomes for these series. ${ }^{13}$

\begin{tabular}{|c|c|c|c|c|c|c|c|c|}
\hline Table 2.1 & Revision errors $\mathrm{i}$ & level c & cyclic: & npone & & & & \\
\hline Filter & $\mathrm{n}=0$ & $n=1$ & $\mathrm{n}=2$ & $n=3$ & $n=4$ & $n=5$ & $n=6$ & $n=7$ \\
\hline HP_129600 & 1.12 & 0.50 & 0.24 & 0.12 & 0.11 & 0.10 & 0.09 & 0.00 \\
\hline HP_10 $10^{6}$ & 0.93 & 0.49 & 0.44 & 0.22 & 0.10 & 0.05 & 0.04 & 0.00 \\
\hline BK_18-96 & 0.58 & 0.45 & 0.20 & 0.11 & 0.10 & 0.10 & 0.05 & 0.00 \\
\hline BK_18-120 & 0.59 & 0.52 & 0.21 & 0.10 & 0.10 & 0.09 & 0.07 & 0.00 \\
\hline CF_18-96 & 0.44 & 0.30 & 0.12 & 0.08 & 0.06 & 0.06 & 0.05 & 0.00 \\
\hline CF_18-120 & 0.44 & 0.30 & 0.19 & 0.09 & 0.05 & 0.03 & 0.03 & 0.00 \\
\hline
\end{tabular}

The results from table 2.1 confirm the observations in figures 2.2 to 2.4 . With regard to differences within the filters, or the effect of a change in the input values, the differences in the

\footnotetext{
${ }^{13}$ For the outcomes of the 16 different series, see annex 1 in Bonenkamp (2003).
} 
revision errors of both bandwidths in the $\mathrm{CF}$ and $\mathrm{BK}$ filters are too small to draw clear conclusions. The situation is different for the HP filter. The HP_ $10^{6}$ filter performs better for $n=0$, while HP_129600 performs better for $n=1,2$ and 3. From $n=4$ both the revisions themselves and the differences between them are too small to draw any meaningful conclusions. The results for $n=0$ correspond to the conclusion by De Haan and Vijselaar (1998) that an inflexible trend yields less significant revisions when new figures become available. But from $n=1$ the downside of a high $\lambda$ becomes evident. Compared to $\lambda=129600$, the value $\lambda=10^{6}$ is less able to signal actual fluctuations in the trend in time. These trend changes are picked up after an average of one year of observations $(n=1)$, which leads to revision errors exceeding those of HP_129600.

With regard to the differences between the filters, the most striking is doubtless the revision of the HP filter for $n=0$. Regardless of the value of $\lambda$, the HP-filtered series deviate far more from their 'real' values than series which have been filtered with a band pass filter. Of the two band pass filters, the CF filter performs better than the BK filter; the revision errors in the CF filter are smaller, especially for $n=0$ and $n=1$. The suspicion already evident from figures 2.2 to 2.4 is confirmed when more than one series are included in the analysis. The symmetrical BK filter, which uses an extrapolation method to extend the series artificially, is more sensitive to the end values than the asymmetrical CF filter.

In short, both the graphical exercise and the quantitative analysis show that the HP filter is more sensitive to the end values than the band pass filters. Of the two band pass filters, the CF filter performs better than the BK filter. This sensitivity analysis is based on a single time moment. A repetition of this experiment for several time moments is an option for future research. ${ }^{14}$ It does not seem very likely, however, that a dynamic analysis will change these findings significantly. After all, our experiment was based on several time series which, around

${ }^{14}$ Den Reijer (2002) conducted a dynamic sensitivity analysis for the HP filter (with $\lambda=1.000 .000$ ) and the CF filter (with a bandwidth of 18-120). He concludes that the differences between the two filters are small. It should be noted that this analysis was based on only a single time series. 
the time moment at which the analysis was conducted, differed sharply in terms of their movements. On the basis of the above findings, the series in the revised CPB leading indicator are filtered with the CF filter. The bandwidth of 18-120 months has been retained, because a wider bandwidth makes it easier to distinguish between relevant cycles and irrelevant cycles.

\subsection{Structure of the CPB leading indicator}

The CPB is interested not only in 'economic activity' in general, as summarised in the GDP figure, but also in the development of key components of the economy. If growth accelerates, it is relevant to know whether the growth impulse originates from abroad or at home. It is also interesting to know in which sector or sectors growth accelerates first. That is why the CPB leading indicator consists of subindicators for both expenditure categories ('demand') and production sectors ('supply'). Public spending has also been included in the system as a separate expenditure category. This structure of the $\mathrm{CPB}$ indicator is quite unique, also by international standards. ${ }^{15}$ Figure 2.5 shows the ten components which are distinguished in the CPB-system of leading indicators.

${ }^{15}$ Several years ago a comparable version of the CPB system was applied to the Belgian economy. See Lebrun (1999). 


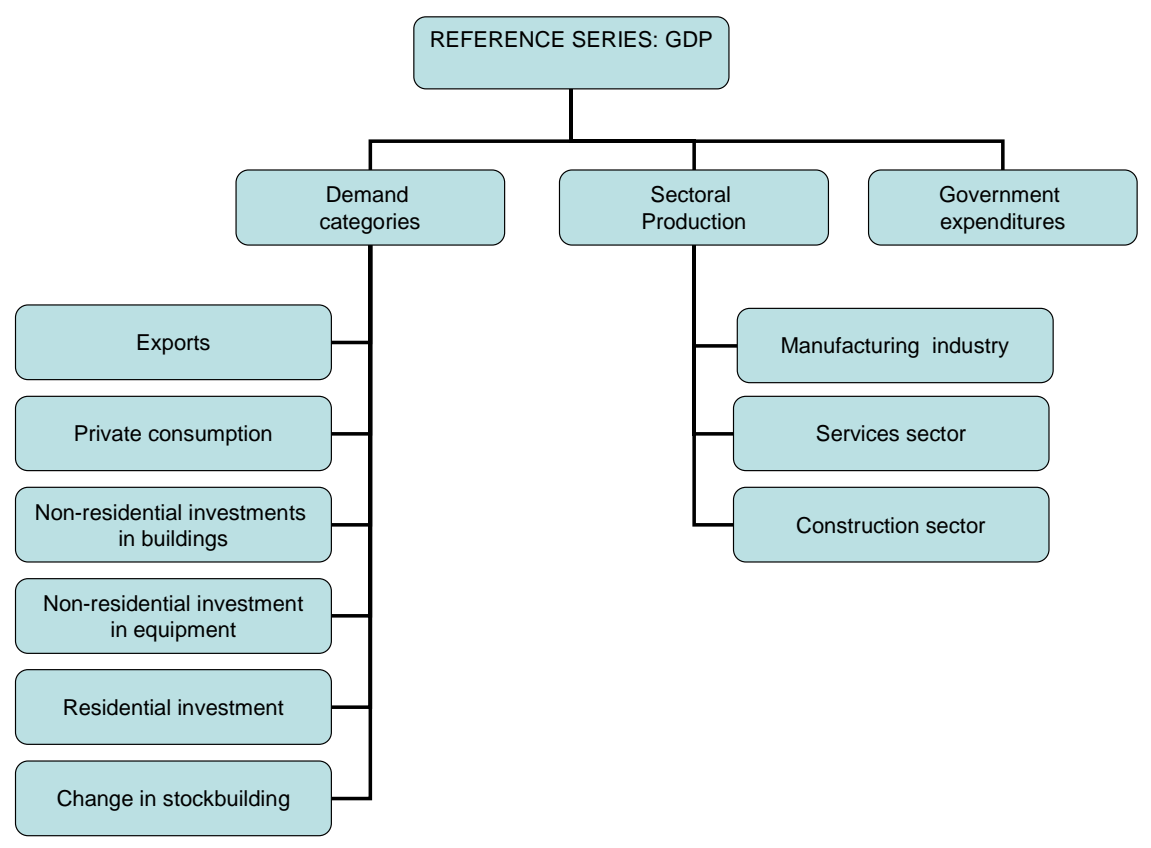

The CPB's approach has three advantages over the usual structure, in which the basic series are directly linked to a single specific reference series. Firstly, the indicator provides more information, because it is possible to discover which expenditure categories or production sectors will underpin GDP growth in the future. It is thus easier to understand and tell the story behind the movements of the indicator. Secondly, because of its structure the CPB leading indicator can be used as an instrument of verification. The indicator can be compared with projections resulting from the macro-economic model used, not only with regard to output, but also consumption or investment for instance (see also section 5). Thirdly, a detailed structure also offers more options to select series. Both series relating to demand components and to specific sectors can be examined. This gives a greater assurance that a theoretical correlation can be established between a reference series and a basic series.

GDP is determined not only by expenditure and production in the market sector, but also by expenditure and production by the public sector. The original CPB leading indicator took no 
account of the latter. This is a drawback, certainly for those years when public spending makes a substantial contribution to GDP growth, as was the case in the Netherlands between 19972002 for instance. For that reason the revised CPB leading indicator has been supplemented with a subindicator for the public sector. Government expenditure and production in a particular year (i.e. calendar year) are laid down in the Budget Memorandum, which is published in September of the previous year. The government budget outlined in the Budget Memorandum can be regarded as the best available leading indicator for public spending and output. It remains an indicator, because not all the plans unveiled by the government in the Budget Memorandum will be realised. Hence new information is incorporated into this projection in the course of the year.

In the CPB system the reference series is thus separated in 10 components: six expenditure demand categories, three sectoral production variables and government expenditures (see figure 2.5). For each of these components an indicator is constructed. The aggregate of these indicators is called the CPB leading indicator.

\section{Composition of the CPB leading indicator}

\subsection{Selected series and weighting scheme}

The process of selecting series to be used in the CPB leading indicator corresponds to the usual NBER methodology. After determining the cyclical component of each series, we then determined on the basis of cross-correlations and the predictive quality of dating turning points which series are usable and what the optimum lead time is. From the many series considered we eventually selected 25 series as components of the CPB leading indicator (see table 3.1).${ }^{16}$ In some areas it was possible to include many indicators, but in others only three or four proved

\footnotetext{
${ }^{16}$ The choice of the selected series is based on Bonenkamp (2003).
} 
suitable. The choice is very limited for private consumption and production of the services sector in particular.

The prediction horizon of the CPB leading indicator depends on lead times of the series and on the speed with which series become available. On the basis of the composition presented in table 3.1, the prediction horizon is very limited. Some variables have a lead of only three of four months. Most of the variables have also a publication lag of one or two months. As a result there is for some variables almost no effective lead. Dropping these variables would reduce the quality of the leading indicator. That is why we opted to 'extrapolate' a limited number of series in order to shift the prediction horizon several months. This is done by estimating a time series model (ARIMA) per series, and then predicting several months on that basis. ${ }^{17}$ Table 3.1 shows which series are extrapolated. By application of this method we have for each component a lead of least three months, compared with the last realisations of GDP.

There are several methods available for weighting the selected basic series in a composite indicator of economic activity:

- the method of principal components;

- weighting with regression analysis

- weighting scheme on the basis of correlations;

- weighting scheme with equal weights

The first method, principal components analysis, is often applied in the context of indicators of economic activity. The indicators for the Dutch economy of the Nederlandsche Bank (DNB) and the CCSO Centre for Economic Research, for instance, use this method. ${ }^{18}$ This is an advanced multivariate technique which boils down to the optimum distillation of common

\footnotetext{
${ }^{17}$ See McGuckin, Ozyildirim and Zarnowitz (2003).
}

${ }^{18}$ See Berk and Bikker (1995) and Jacobs et al. (1997). 
fluctuations in a set of variables. ${ }^{19}$ A drawback of principal components analysis is that this method does not take explicit account of the relationship between the basic series and the reference series, and this has to be 'predicted'.

The weights can also be determined with the help of regression analysis. This method has the disadvantage that in theory it can only be applied when the variables are not linked to each other. But this condition can almost never be met in the case of an indicator of economic activity. ${ }^{20}$ An alternative method uses correlation coefficients between a basic series and a reference series as weights. The advantage of this method is that series with a higher statistical correlation with the reference series also receive a heavier weighting. In the previous version of the CPB leading indicator the coefficients were calibrated in this way. ${ }^{21}$

The simplest method, and this is used by the OECD for instance, uses equal weights. ${ }^{22}$ Bonenkamp (2003) has shown that the results between de three methods do not differ that much. That is why, for the sake of simplicity, we have used equal weights in the weighting of indicators for the various components.

\footnotetext{
${ }^{19}$ For a brief technical exposition of the method of principal components, see Jacobs (1998), pp. 57-58.

${ }^{20}$ Correlation of the regressors leads to multicollinearity. Consequently the estimated coefficients are unbiased, but they have a high standard error. Thus the information value of the coefficients is low.

${ }^{21}$ See Kranendonk (1990), p. 30.

${ }^{22}$ See OECD (1987).
} 


\begin{tabular}{|c|c|c|c|c|c|}
\hline \multirow{2}{*}{$\begin{array}{l}\text { Table } 3.1 \\
\text { Expenditures }\end{array}$} & \multicolumn{5}{|c|}{ Composition and lead of CPB leading indicator's components } \\
\hline & & Lead & Sectors & & Lead \\
\hline \multirow[t]{5}{*}{ Consumption } & Retail trade confidence indicator & 12 & $\begin{array}{l}\text { Manufacturing } \\
\text { Industry }\end{array}$ & Production trend observed & 5 \\
\hline & Economic climate & 15 & & Money supply (M1, real) & 13 \\
\hline & Bankruptcies $^{a}$ & $3^{b}$ & & $\begin{array}{l}\text { IFO business climate } \\
\text { (expectations) }\end{array}$ & 6 \\
\hline & Willingness to buy & 12 & & OECD Leading indicator Europe & 5 \\
\hline & & & & Total inflow orders & 7 \\
\hline \multirow[t]{6}{*}{ Exports } & Exchange rate dollar euro & $6^{\mathrm{c}}$ & & Production expectations & 6 \\
\hline & Money supply (M1, real) & 13 & & & \\
\hline & IFO business climate (expectations) & 6 & $\begin{array}{l}\text { Construction } \\
\text { sector }\end{array}$ & $\begin{array}{l}\text { Production tendency non- } \\
\text { residential buildings }\end{array}$ & 12 \\
\hline & Long-term interest rate ${ }^{a}$ & 20 & & $\begin{array}{l}\text { Production tendency residential } \\
\text { buildings }\end{array}$ & 14 \\
\hline & OECD Leading indicator Europe & 4 & & $\begin{array}{l}\text { Buildings permits granted, } \\
\text { private non-residential }\end{array}$ & $6^{b}$ \\
\hline & Inflow foreign orders & 6 & & $\begin{array}{l}\text { Buildings permits granted, } \\
\text { residential }\end{array}$ & $6^{\mathrm{b}}$ \\
\hline \multirow{3}{*}{$\begin{array}{l}\text { Non- } \\
\text { residential } \\
\text { investment } \\
\text { (buildings) }\end{array}$} & $\begin{array}{l}\text { Production tendency non- } \\
\text { residential buildings }\end{array}$ & 4 & & Long-term interest rate ${ }^{a}$ & 22 \\
\hline & $\begin{array}{l}\text { Buildings permits granted, } \\
\text { private non-residential }\end{array}$ & $3^{b}$ & & OECD Leading indicator Europe & 12 \\
\hline & Bankruptcies $^{a}$ & $7^{\mathrm{b}}$ & & OECD Leading indicator US & 16 \\
\hline \multirow{5}{*}{$\begin{array}{l}\text { Non- } \\
\text { residential } \\
\text { investment } \\
\text { (equipment) }\end{array}$} & $\begin{array}{l}\text { Production tendency non-residential } \\
\text { buildings }\end{array}$ & 6 & Services sector & $\begin{array}{l}\text { Buildings permits granted, } \\
\text { non-residential }\end{array}$ & $4^{b}$ \\
\hline & $\begin{array}{l}\text { Capacity utilisation manufacturing } \\
\text { sector }\end{array}$ & 8 & & Retail trade confidence indicator & 9 \\
\hline & Consumer confidence & 4 & & Bankruptcies $^{\mathrm{a}}$ & $4^{b}$ \\
\hline & Inflow domestic orders & 14 & & & \\
\hline & Orderposition & 8 & & & \\
\hline \multirow[t]{3}{*}{$\begin{array}{l}\text { Residential } \\
\text { investment }\end{array}$} & $\begin{array}{l}\text { Production tendency residential } \\
\text { buildings }\end{array}$ & 6 & Government & $\begin{array}{l}\text { Government expenditure } \\
\text { (CPB forecast based on Budget } \\
\text { memorandum) }\end{array}$ & 0 \\
\hline & Buildings permits granted, residential & $5^{b}$ & & & \\
\hline & Long-term interest rate ${ }^{a}$ & 14 & & & \\
\hline \multirow{3}{*}{$\begin{array}{l}\text { Change in } \\
\text { stockbuildings }\end{array}$} & IFO business climate & 7 & & & \\
\hline & Inflow domestic orders & 7 & & & \\
\hline & $\begin{array}{l}\text { Producer confidence manufacturing } \\
\text { industry }\end{array}$ & 9 & & & \\
\hline $\begin{array}{l}\text { a } \text { Inverted. } \\
\text { b Series extrapol } \\
{ }^{c} \text { Exchange rate } c\end{array}$ & $\begin{array}{l}\text { ated with ARIMA-forecast. } \\
\text { compared with twelve months ago }\end{array}$ & & & & \\
\hline
\end{tabular}




\section{$3.2 \quad$ Aggregate}

After the indicators have been constructed, with the help of the basic series, for the 10 different components, an aggregate is compiled which serves as the indicator for GDP. To that end the subindicators have to be weighted. This is done in two stages. First the subindicators for the expenditure categories are weighted into an 'expenditure indicator' (left column in figure 2.5), and those for production sectors into a 'production indicator' (column in the mid of figure 2.5). These two indicators together constitute the two main components of the CPB leading indicator. These two components are merged with public spending into the aggregate.

How is the weighting scheme determined? Until recently the expenditure categories were weighted at their nominal share in total expenditure, with an adjustment for the different variances of the components. In this way investments were given a slightly heavier weighting, because their cyclical fluctuations are relatively large. Conversely, the weighting of consumption was reduced somewhat. The production sectors were weighted in the same way, that is, at their nominal shares in total output.

In the course of the project on the revision of the CPB leading indicator we found that this method yielded disappointing results. For more recent years in particular the aggregated indicator did not adequately reflect the actual economic situation. The reason why the old method did not function properly may well be related to the changed filter method. After all, there is no guarantee that weighting components which have been filtered separately will yield the same result as filtering the trend component directly from the aggregate of those components. $^{23}$

\footnotetext{
${ }^{23}$ Incidentally, this was not guaranteed either under the phase-average-trend (PAT) filter method applied until recently.
} 
The current approach for weighting into the CPB leading indicator is based on regression analysis. By regressing the actual series for the GDP components (both expenditure categories and production sectors) on the actual GDP series, we have tried to estimate the optimum weighting. We only used the cyclical components of the series. Unfortunately unrestricted regression leads to negative shares for the smaller components of GDP, such as public spending, residential investment and other private non-residential investment. Setting the weights of these smaller components at 5\% yielded plausible weights, which have been included in table 3.2 .

\begin{tabular}{|c|c|c|c|}
\hline Structure of CPB leadir & (in \%) & & \\
\hline Reference series & Expenditures & Sectoral production & Total \\
\hline Exports & 25,0 & & 10,6 \\
\hline Private consumption & 40,0 & & 17,0 \\
\hline Non-residential investment in buildings & 10,0 & & 4,3 \\
\hline Non-residential investment in equipment & 5,0 & & 2,1 \\
\hline Residential investment & 5,0 & & 2,1 \\
\hline Change in stockbuilding & 15,0 & & 6,4 \\
\hline Total expenditures & & & 42,5 \\
\hline Manufacturing industry & & 30,0 & 15,8 \\
\hline Services sector & & 55,0 & 28,9 \\
\hline Construction sector & & 15,0 & 7,9 \\
\hline Total sectoral production & & & 52,5 \\
\hline Government expenditures & & & 5,0 \\
\hline Total (GDP) & 100 & 100 & 100 \\
\hline
\end{tabular}

By combining the information in the tables 3.1 and 3.2 it is possible to infer the weighting of the basic series in the composition of the CPB leading indicator. In table 3.3 the series are clustered in a number of different sources from which the indicators can be obtained, namely 
international indicators, monetary variables, business surveys among manufacturers, business surveys in the construction industry, business surveys in the services sector, consumer surveys and other indicators. The table shows that three of the 25 series have a relatively heavy weighting of more than $10 \%$, namely business confidence in the retail sector, the number of bankruptcies and the number of permits for industrial and commercial buildings. This is because only three series have been selected for 'production in the services sector' and 'private consumption', and these two categories have a considerable share in the total. Partial comparisons of the basic series confirm, however, that these series are more closely correlated with GDP than the other series. That is why we have decided not to reduce the weighting of these three series.

The clustering of the series shows that the various sources each contribute between $10-15 \%$. This indicates that the CPB leading indicator is based on a broad range of information with a relatively balanced composition.

\subsection{Long-leading indicator}

Table 3.1 shows that many of the series have a lead time of four to seven months. Bearing in mind the delayed availability of information and the extension of some series, this makes it possible to detect a turnaround at most one or two quarters ahead. However, there are also a number of variables with lead times of nine months or longer. These variables make it possible to look three quarters ahead. But because only a limited number of series are involved, these series are only combined for the aggregate (GDP) and not for the individual components. To that end we determined the optimum lead time in relation to GDP, and we did not take the lead time from table 3.1. Table 3.3 includes the composition of this long-leading indicator in the right-hand column, with the lead time shown in brackets. A summary of the whole system of indicators in model form is provided in annex 1 . 
Table 3.3 Weight of the indicator series in the CPB leading indicator and long-leading indicator

Series

CPB leading indicator

Long-leading

(lead in months)

International indicators

13,0

IFO business climate

IFO business climate (expectations)

2,1

Leading indicator Europe (OECD)

4,4

5,4

Leading indicator US (OECD)

1,0

Monetary variables

11,0

Exchange rate dollar euro

1,8

Money supply (M1, real)

5,4

$14,3(13)$

Long-term interest rate (inverse)

$14,3(20)$

Business surveys manufacturing industry

3,5

15,0

$\begin{array}{lr}\text { Capacity utilisation rate manufacturing industrie } & 0,4\end{array}$

$\begin{array}{ll}\text { Production trend observed } & 2,6\end{array}$

Inflow domestic orders $\quad 2,6$

$\begin{array}{ll}\text { Inflow foreign orders } & 1,8\end{array}$

$\begin{array}{lr}\text { Total inflow orders } & 2,6\end{array}$

$\begin{array}{ll}\text { Orderposition } & 0,4\end{array}$

$\begin{array}{ll}\text { Producer confidence manufacturing industry } & 2,1\end{array}$

$\begin{array}{lr}\text { Production expectations } & 2,6\end{array}$

Business surveys construction $\quad 5,0$

$\begin{array}{lr}\text { Production tendency non-residential buildings } & 2,8\end{array}$

$\begin{array}{lr}\text { Production tendency residential buildings } & 1,7\end{array}$

$\begin{array}{lr}\text { Business surveys servicessector } & 14,0\end{array}$

$\begin{array}{lr}\text { Producer confidence retail sector } & 13,9\end{array}$

$\begin{array}{lr}\text { Questionnaire amongst consumers } & 9,0\end{array}$

$\begin{array}{ll}\text { Consumer confidence } & 0,4\end{array}$

Economic climate $\quad 4,3$

$14,3(15)$

Willingness to buy $\quad 4,3$

Other indicators

$\begin{array}{lr}\text { Bankruptcies (inverse) } & 15,3\end{array}$

$\begin{array}{lr}\text { Buildings permits granted, non-residential } & 12,0\end{array}$

$14,3(10)$

$\begin{array}{lr}\text { Buildings permits granted, residential } & 1,7\end{array}$

CPB-forecast government expenditure $\quad 5$

Total 


\subsection{Role and significance of IFO data}

Of the 25 selected indicators, four are based on economic developments in other countries. ${ }^{24}$ For an open economy like the Dutch, international economic conditions are very important. Both upturns and slowdowns in economic growth often receive an initial impulse from abroad. After a certain time lag this has a ripple effect in consumer spending and/or private nonresidential investment. When the economy is in recession, as in 2003, it therefore makes sense to analyse indicators from other countries to see whether they give off any signs of recovery. Since Germany is the destination of around $25 \%$ of Dutch goods exports, an indicator for the Dutch economy should pay special attention to German leading indicators.

Ever since its introduction in 1990, the CPB leading indicator has relied on two major international sources of indicators, the OECD and the IFO. The CPB indicator uses the OECD's leading indicators for Europe and the United States. These serve as proxies for the general international climate. The CPB indicator has also used the IFO's business climate indicator for German manufacturing industry. As part of the revision of the CPB indicator, we analysed the contribution of the IFO indicator in detail. The findings are discussed in this section.

The business climate for the German economy was included in 1990 as an indicator for nonenergy exports and manufacturing output, in both cases with lead times of five months. In the course of the recent study it emerged that the optimum lead time was now only a few months, which may be related to shorter production and delivery times. The current method diverges in three ways from the approach adopted in 1990, with the first point having a particularly significant bearing on the outcomes:

\footnotetext{
${ }^{24}$ These are the OECD's leading indicators for Europe and the United States and the German IFO's business climate indicator and its component on expectations for the near future (see table 3.1).
} 
- The trend-based development is now eliminated with a different filter technique. In the past the phase-average-trend (PAT) method was used; since the revision the Christiano-Fitzgerald filter is used (see section 2.2).

- In the past the business climate indicator was not adjusted for the trend; now it is.

- The time series for exports and manufacturing output have been changed twice since 1990 as a result of international revisions of the national accounts.

With the current series and filters the lead time is only two to three months. This is not long enough to be of any use. That is why we analysed separately the two questions of which the business climate indicator is composed, namely an assessment of the current situation and the expectations for the near future. Table 3.4 shows that the question relating to expectations for the near future has a lead time of six months or longer. Partly on the basis of an analysis of turning points, the expectations variable has been included in the revised CPB leading indicator with a lead time of six months (see table 3.1). The question relating to the current situation has no lead time and therefore cannot be used. It is also apparent from the table that in recent years the expectations question has been much more closely linked to the reference series, since the correlation coefficient rose from $0.3-0.4$ in the first period to around 0.75 in the second period.

\begin{tabular}{|c|c|c|c|c|}
\hline \multirow[t]{3}{*}{ Table 3.4} & th exports a & Ifacturing in & \multirow{2}{*}{\multicolumn{2}{|c|}{ Lead (months) }} \\
\hline & \multicolumn{2}{|l|}{ Correlation } & & \\
\hline & $1975-1988$ & 1989-2002 & $1975-1988$ & 1989-2002 \\
\hline \multicolumn{5}{|l|}{ Exports } \\
\hline IFO business climate & 0,61 & 0,80 & 2 & 2 \\
\hline${ }^{*}$ current situation & 0,71 & 0,80 & 0 & -1 \\
\hline${ }^{*}$ expectations & 0,25 & 0,76 & 7 & 6 \\
\hline \multicolumn{5}{|l|}{ Manufacturing industry } \\
\hline IFO business climate & 0,74 & 0,85 & 4 & 3 \\
\hline${ }^{*}$ current situation & 0,84 & 0,86 & 3 & 0 \\
\hline${ }^{*}$ expectations & 0,38 & 0,74 & 9 & 7 \\
\hline
\end{tabular}


Figure 3.1 shows that the correlation was weaker during the first half of the 1980 s in particular, but that it was much stronger between 1986-2000. This applies both for the dating of the turning points and for the intensity of the fluctuations. A striking aspect in recent years is that the upswing for 2002 flagged up in the expectations question of the business climate survey did not materialise, probably partly due to geopolitical uncertainties.

Figure 3.1 Cyclical pattern of Exports, manufacturing industry and IFO-expectations ${ }^{1}$
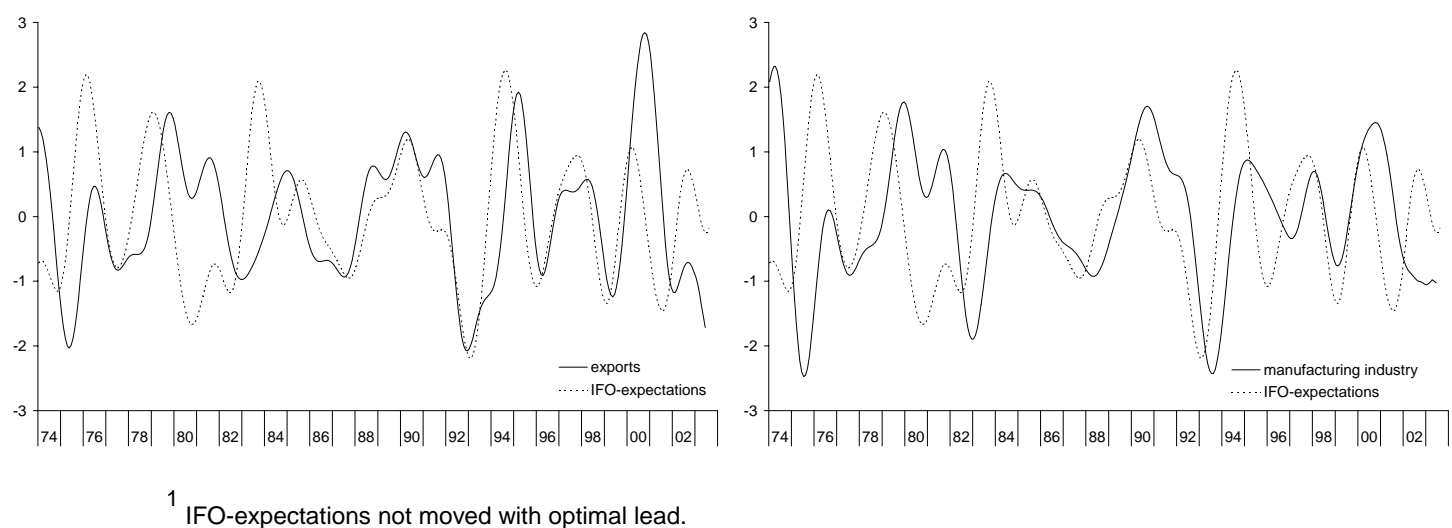

Incidentally, the influence of the IFO business climate indicator on the overall CPB leading indicator is greater than the effects through exports and manufacturing output discussed here. The CPB indicator uses the average IFO business climate indicator for stock building, because in this case the lead time of seven months is sufficient (see table 3.1). Together the IFO series contribute $6.5 \%$ to the CPB leading indicator. This contribution is the same as that of the OECD's two leading indicators. Compared to the contribution of variables from surveys among Dutch manufacturers $(15 \%)$, the contribution of the international indicators is limited.

International indicators play a relatively larger role in the long-leading indicator, which looks slightly further ahead into the future. As explained in section 3.3, the long-leading indicator is not calculated for the individual components, but directly for GDP. Among the international indicators, only the IFO's expectations question among German manufacturers has a sufficient lead time (nine months) for inclusion. Its contribution to the long-leading indicator is $14.3 \%$. The variables from the survey among Dutch manufacturers have too short a lead time 
to be included in the long-leading indicator. Thus the German expectations variable is the most important source of information for the longer horizon (i.e. two to three quarters ahead) for Dutch exports and manufacturing output. This because the other variables in the long-leading indicator relate to household spending (consumer confidence), production in the services sector (business confidence among retailers) and construction (building permits), or they are of a general nature (money supply and interest rates).

\section{Performance of CPB leading indicator}

Section 3 explains the composition of the CPB leading indicator. In this section we will briefly discuss the result. In figure 4.1 the 'realisation' line represents the economic cycle of GDP. The indicator, based on the 25 selected series, can track this line quite accurately. The correlation coefficient between the indicator and the reference series is high, 0.82 . The main upturns and downturns are represented quite accurately by the indicators. Only the subcycles during the mid 1970s are not recorded. ${ }^{25}$ The intensity of the cyclical upward and downward phases in the indicator corresponds more or less with the actual fluctuations. In most cases the turning points are predicted reasonably accurately, but on several occasions the turnaround is signalled too soon (the peak in 2000) or too late (the trough in 1989). These 'misses' show that the instrument should be used with a degree of caution.

\footnotetext{
${ }^{25}$ Incidentally, in the selection process the early years were weighted less heavily.
} 


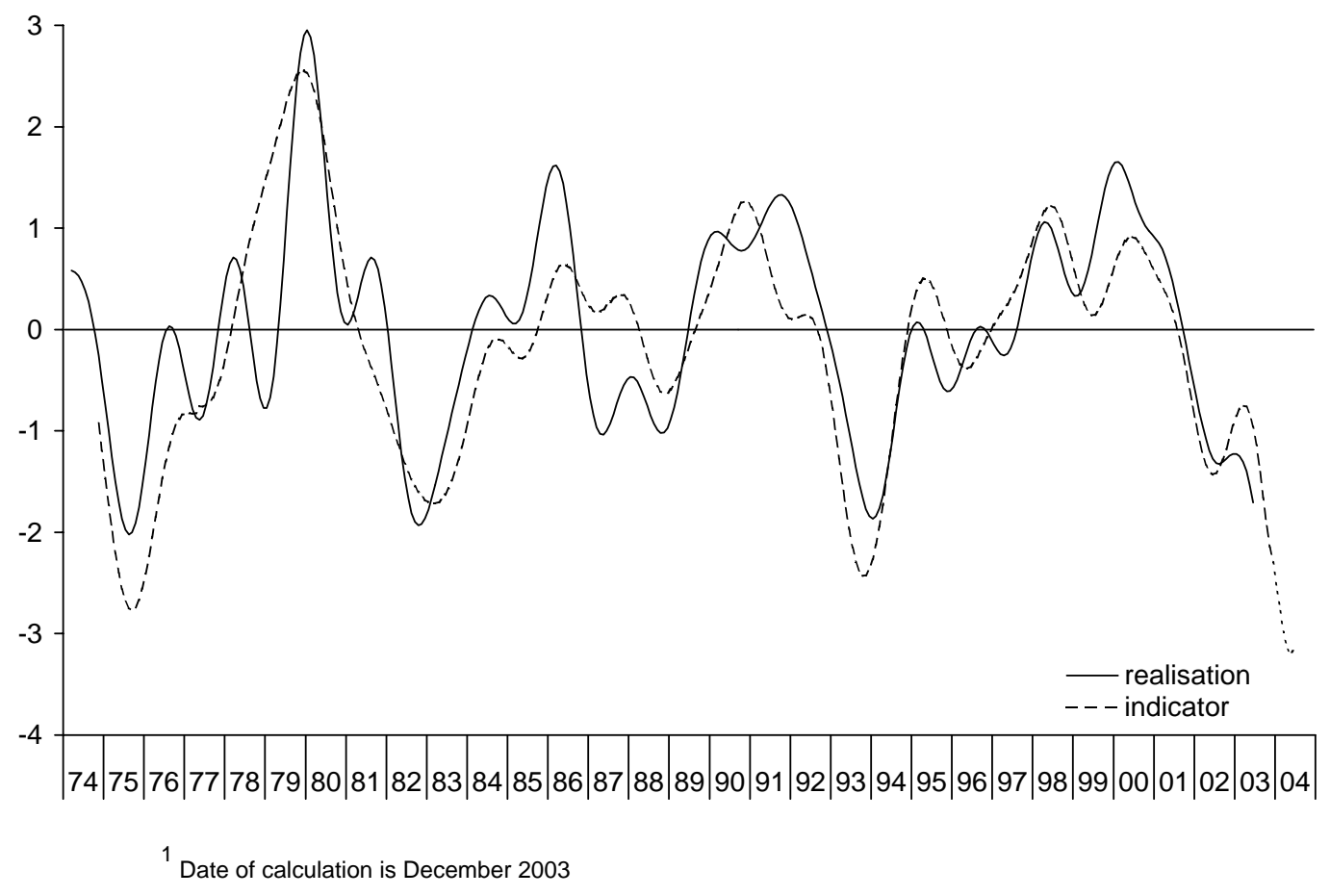

The figure also includes the long-leading indicator. To prevent the three lines - realisation, indicator and long-leading indicator - intertwining too much, we have opted for a presentation in which the dynamic of the long-leading indicator is added to the most recent observation of the normal indicator. In the figure the dashes are the based on the CPB leading indicator, and the dots for the most recent months are derived from the long-leading indicator. We have deliberately opted for a change from dashes to dots, because the seven series constituting the long-leading indicator account for only half of the total information. The 'prediction' for the longer time horizon (more than three months ahead, say) is thus based on less information and should therefore be interpreted with particular caution. 
Figure 4.2 shows the actual outcomes and the leading indicators for the 10 components of the CPB leading indicator. They illustrate that the cyclical patterns differ significantly between categories. Private consumption, for example, has only four cycles during the period 19742003, while export shows seven cycles. The indicators for most components perform quite well measured by the number of cycles and the dating of turning points. The performance of the change in stockbuilding is relatively poor, probably caused by statistical measurement problems. The horizon of the indicators of the components differ, depending on the lead of the selected basic series. The indicator for private consumption has in December 2003 information up to September 2004, but most of the other indicators are no further available then up to February or March 2004

\section{Figure 4.2 Components of CPB leading indicator}
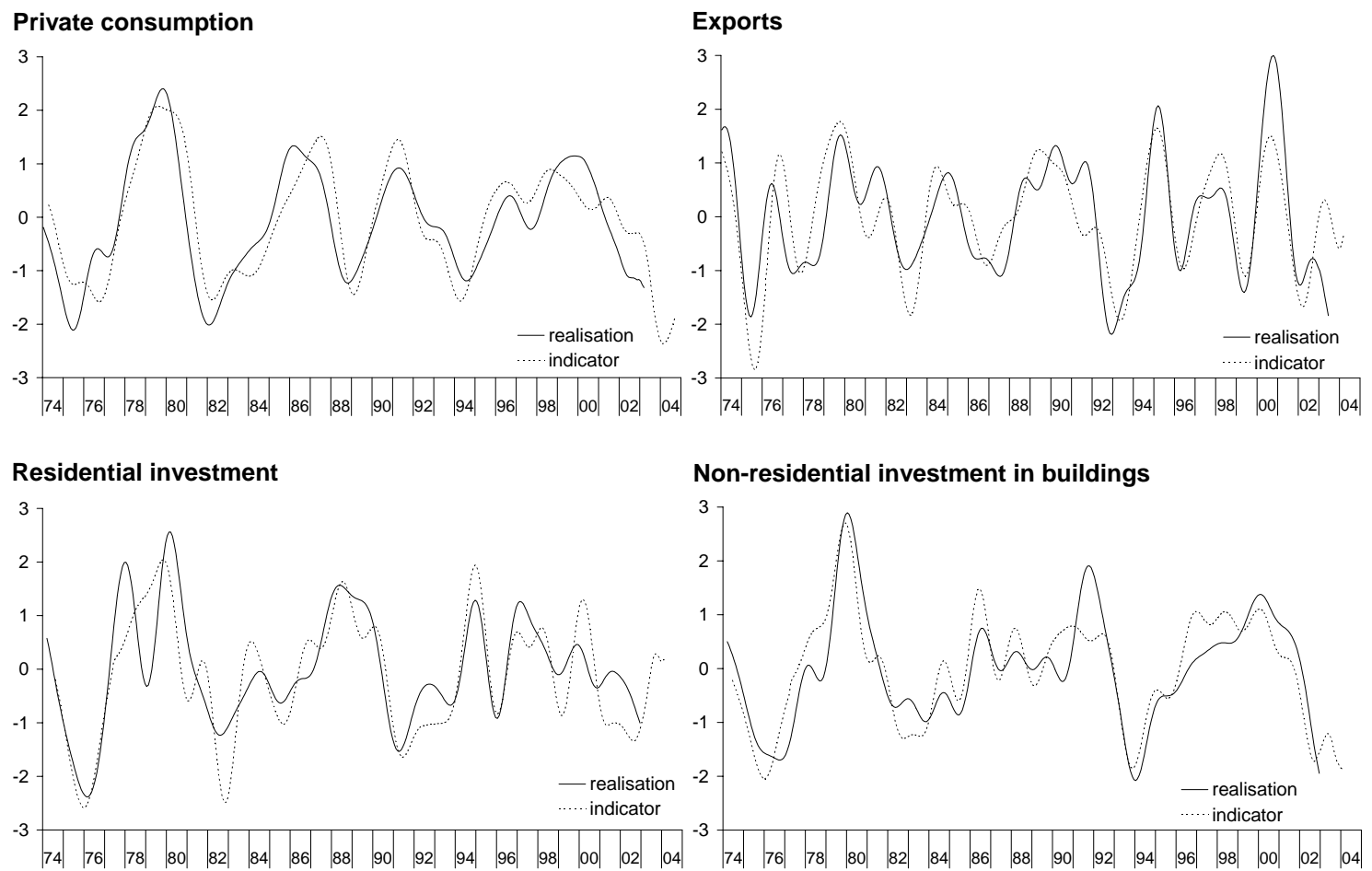
Non-residential investment in equipment

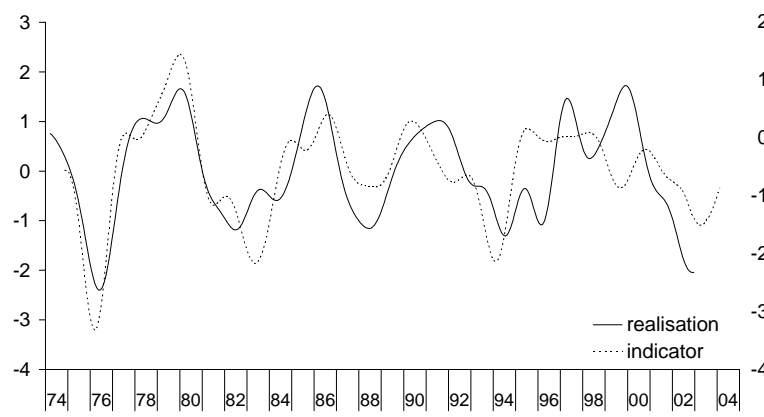

Production manufacturing industry

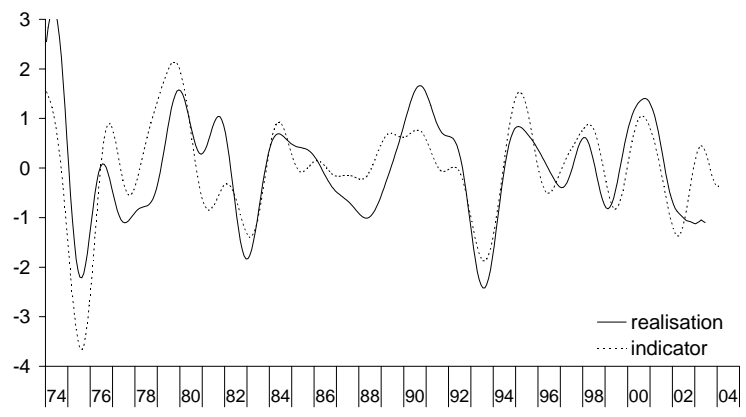

Change in stockbuilding

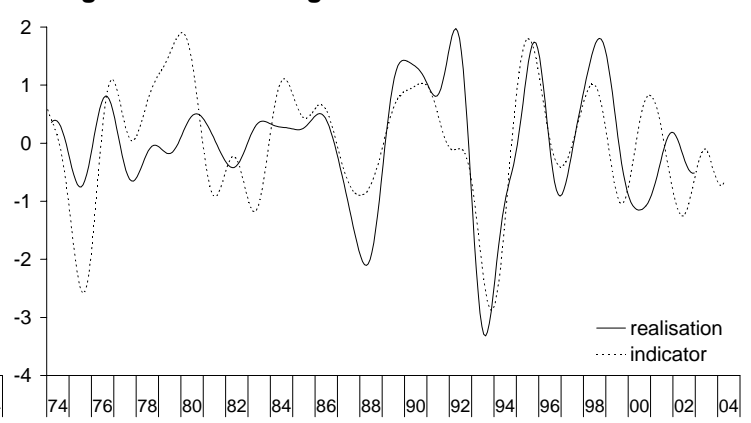

Production services sector

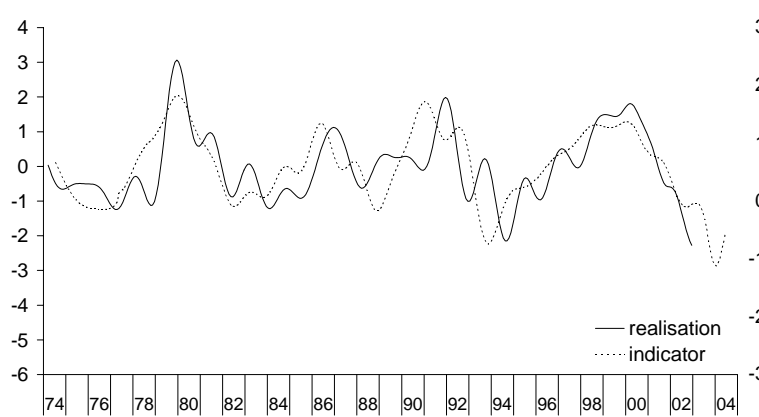

Production construction sector

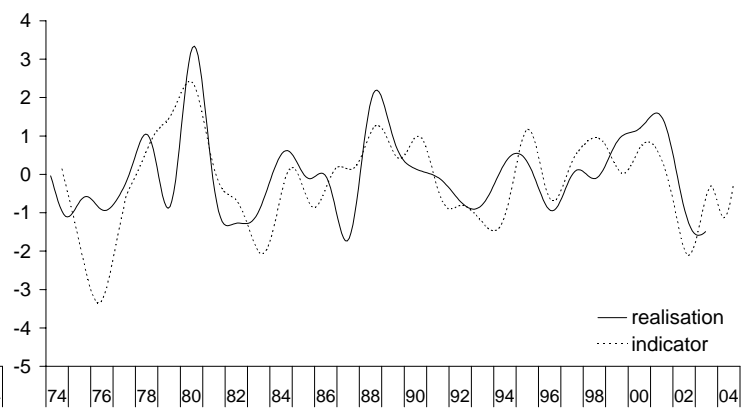

\section{Government expenditures}

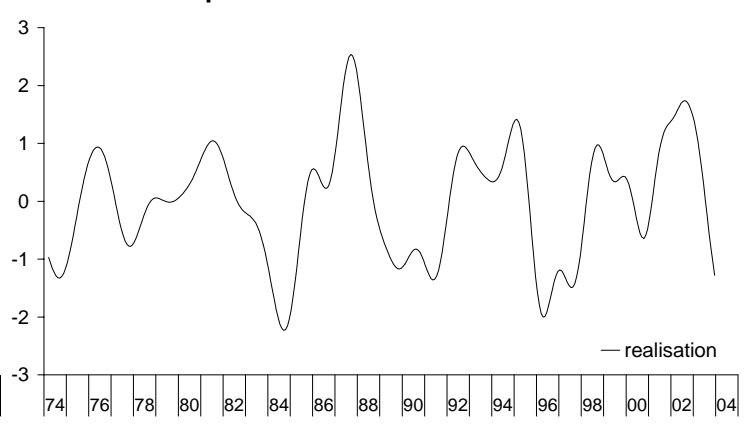




\section{$5 \quad$ Application in practice}

Each quarter the CPB publishes a projection of economic growth for the current and the following year. The quarterly model SAFE plays a key role in the preparation of the forecasts. ${ }^{26}$ This model is fed with data covering the past and with exogenous assumptions on international developments and the government's economic policies. Other information sources, such as the views of experts, are also used in estimating the economy's performance. Figure 5.1 shows the process in schematic form. A key feature is that the preparation of the projections is an iterative process, in which the model assures consistency. ${ }^{27}$ The projections are adjusted via the autonomous terms in the model. This means that the outcomes for specific behavioural equations, such as private consumption, investment or exports, can be adjusted if necessary.

The advantage of this procedure is that the model calculates the consequences for all variables if an adjustment is made for a specific variable.

Information from the CPB leading indicator sometimes prompts an adjustment of the model's projection. The model makes projections on a quarterly basis and takes as much account as possible of the actual outcomes published by Statistics Netherlands (CBS) at regular intervals. Often the indicators provide some information on those quarters for which CBS has not yet published any figures. That is why the signal of a possible turning point in the CPB leading indicator is compared with the profile based on the model's projection. For the current quarter and the following two quarters the analysis attaches considerable weight to an acceleration or deceleration of growth as indicated by the barometer.

\footnotetext{
${ }^{26}$ See CPB (2003).

${ }^{27}$ For more information, see Kranendonk and Jansen (1997).
} 
This can be illustrated with two examples. A relatively positive development of disposable household incomes leads to an optimistic projection for household consumption. But if households report in the monthly survey that they do not have much confidence in the economic outlook or if they are pessimistic about their own financial situation, this signal could lead to a more cautious projection of consumer spending than would have happened purely on the basis of the relevant economic variables.

Similarly it may be necessary to temper the projection for exports if Dutch businesses are still pessimistic about orders received from abroad. In section 3.4 we highlighted the usefulness of analysing international indicators in addition to Dutch indicators and of seeing what signals they give off. Because of the importance of developments in Germany, strong or weak confidence among German manufacturers, as reflected in the expectation component of the IFO business climate indicator, may thus be sufficient reason to reconsider the model's export projection and perhaps to adjust it. 
Figure 5.1 Process of making short-term forecasts at CPB

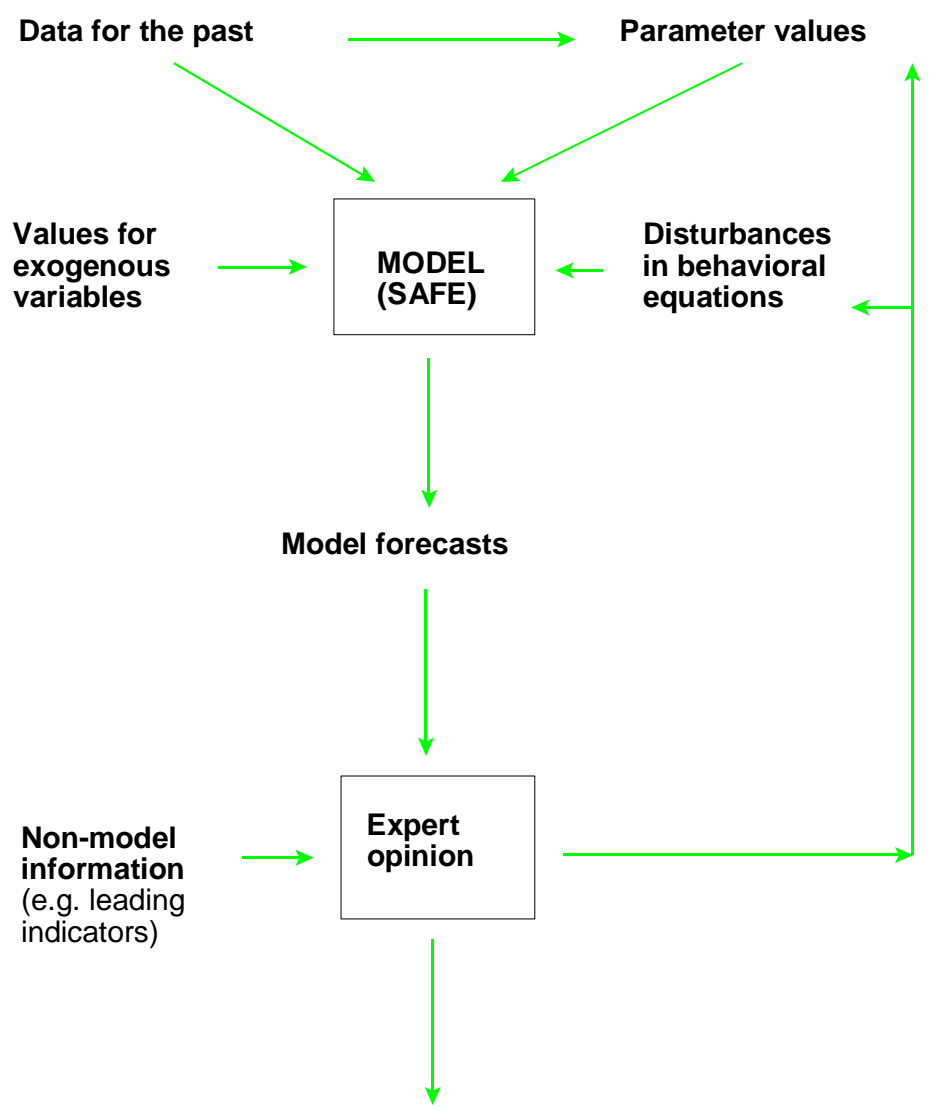

Published forecasts 


\section{Summary}

Since 1990 CPB uses a leading indicator for the Dutch economy. The structure of the CPB leading indicator is tailored to its use as a supplement to model-based projections, and thus has a unique character in several respects. Gross domestic product (GDP) is used as the reference series. CPB is interested not only in 'economic activity' in general, as summarised in GDP, but also in the development of key components of the economy. That is why the CPB leading indicator consists of subindicators for both expenditure categories ('demand') and production sectors ('supply'). Public spending has also been included in the system as a separate expenditure category.

CPB's methodology, which is based on the widely applied NBER methodology, uses so- called 'deviation cycles'. The elimination of trend-based components from the time series used in this approach is an important aspect of this approach. A serious drawback of the application of a filter is known as the 'end-point problem', which arises because the addition of new or revised observations changes the filtered values of previous observations. Both a graphical exercise and a quantitative analysis show that the Hodrick Presscott filter is more sensitive to the end values than band pass filters. Of the two analysed band pass filters, the Christiano Fitzgerald (CF) filter performs better than the Baxter and King (BK) filter and is now used in the revised CPB leading indicator

From the many series considered 25 were selected for the 10 components of the CPB leading indicator. A clustering of these series shows that the different sources, namely international indicators, monetary variables, business surveys among manufacturers, business surveys in the construction industry, business surveys in the services sector, consumer surveys and other indicators contribute each between 10-15\%. This leading indicator has a lead of 3 to 4 months. The indicator can track the cyclical development of real GDP rather well. The correlation 
coefficient between the indicator and the reference series is 0.82 . The main upturns and downturns are represented quite accurately by the indicators.

Seven variables have a lead time of nine months or longer. These variables are combined in a long-leading indicator, which make it possible to look three quarters ahead. The 'prediction' for the longer time horizon is based on less information and should therefore be interpreted with particular caution.

Of the 25 selected indicators, 4 are based on economic developments in other countries. For an open economy like the Dutch, international economic conditions are very important. Both upturns and slowdowns in economic growth often receive an initial impulse from abroad. Just like the two selected OECD's leading indicators for Europe and the US, the two selected IFO series contribute $6.5 \%$ to the $\mathrm{CPB}$ leading indicator of the Dutch economy. Compared to the contribution of variables from surveys among Dutch manufacturers (15\%), the contribution of the international indicators is limited. IFO data about the expectations among German manufacturers play a larger role (14.3\%) in the CPB long-leading indicator.

CPB leading indicator signals are compared with the projections based on the large-scale macro-econometric model used. This can lead to an adjustment of the model's projection by applying add-factors in specific behavioural equations, such as private consumption, investment or exports. 


\section{Annex 1 System of equations CPB leading indicator}

\section{Consumption:}

e $\quad=[\operatorname{dol}(-6)+$ ifoe $(-6)+$ lieur $(-4)-\mathrm{rl}(-20)+\mathrm{ml}(-13)+$ oif $(-6)] / 6$

cp $=[\operatorname{cret}(-12)+\operatorname{ecc}(-15)-\operatorname{br}(-3)+\operatorname{wtob}(-12)] / 4$

ib $=[\operatorname{bpn}(-3)+\operatorname{ptn}(-4)-\operatorname{br}(-7)] / 3$

ie $\quad=[\operatorname{cap}(-8)+\operatorname{ptn}(-8)+\operatorname{ccon}(-4)+\operatorname{oid}(-14)+\operatorname{orp}(-8)] / 5$

ir $\quad=[\operatorname{bpr}(-5)+\operatorname{ptr}(-6)-\operatorname{rl}(-14)] / 3$

st $\quad=[$ ifo $(-7)+\operatorname{oid}(-7)+\operatorname{mcon}(-9)] / 3$

\section{Sectors:}

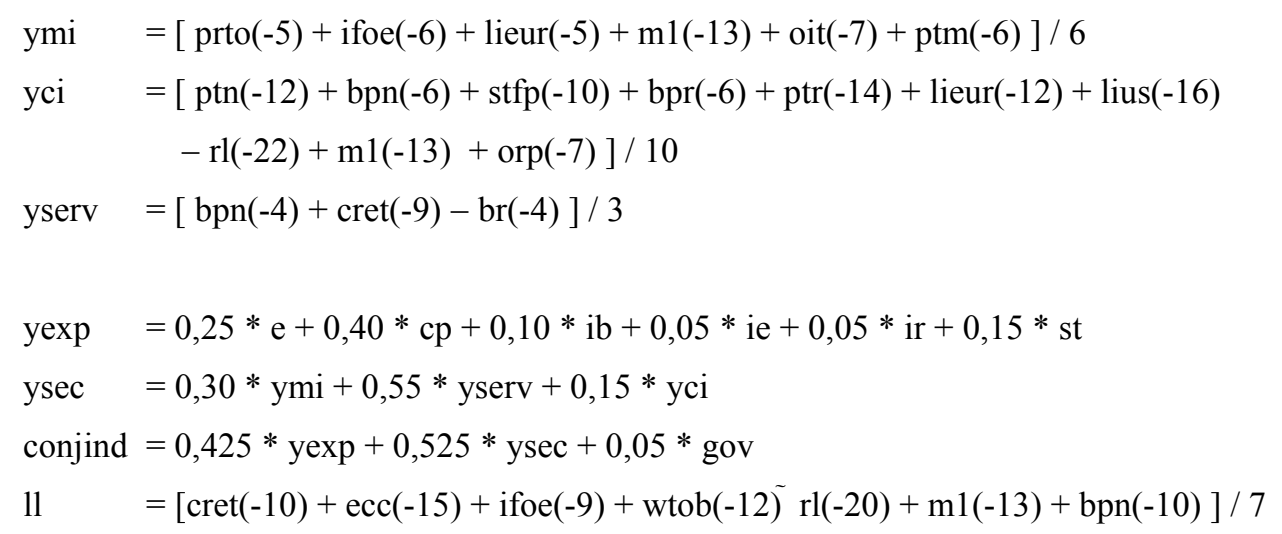

\section{Explanation abbreviations:}

conjind CPB leading indicator

cp private consumption

e exports of goods excluding energy

gov government expenditures

ib non-residential investment in buildings

ie non-residential investment in equipment

ir residential investment

$11 \quad$ long-leading indicator

st change in stockbuildings

yci production construction industry

yexp production, expenditure approach

ymi production manufacturing industry

ysec production, sectoral approach

yserv production services sector 


\section{Indicators:}

bpn buildings permits granted, non-residential

bpr buildings permits granted, residential

br bankruptcies

cap capacity utilisation

ccon consumer confidence

cret retail trade confidence indicator

dol exchange rate dollar euro

ecc economic climate

ifo IFO business climate (manufacturing industry)

ifoe IFO business climate (expectations, manufacturing industry)

lieur leading indicator Europe (OECD)

lius leading indicator United States (OECD)

mcon producer confidence manufaturing industry

m1 money supply (M1, real)

oid inflow domestic orders

oif inflow foreign orders

oit total inflow orders

orp orderposition

prto production trend observed 
ptm production expectations

ptn production tendency non-residential buildings

ptr production tendency residential buildings

rl long-term interest rate

wtob willingness to buy 


\section{References}

Agresti, A. and B. Mojon (2001), 'Some stylised facts on the euro area business cycle', ECB

Working Paper Series no. 95, Europese Centrale Bank, Frankfurt.

Assenbergh, W. van (2000), 'Vernieuwde conjunctuurindicatoren', Themabericht 2000/04, Rabobank, (in Dutch).

Baxter, M. and R. King (1999), 'Measuring business cycles: approximate band pass filters for economic time series', Review of Economics and Statistics, 81, 575-93.

Berk, J.M. and J.A. Bikker (1995), 'International interdependence of business cycles in the manufacturing industry: the use of 'leading indicators' for forecasting and analysis', Journal of Forecasting, 14, 1-23.

Bonenkamp, J.P.M. (2003), 'Herziening van de CPB-conjunctuurindicator', $C P B$

Memorandum 71, Centraal Planbureau, Den Haag. (in Dutch)

Burns A.F. and W.C. Mitchell (1946), 'Measuring Business cycles', Volume 2 of Studies in Business Cycles, National Bureau of Economic Research, New York. 
Chadha, J.S. and C. Nolan (2002), 'A long view of the UK business cycle', National Institute Economic Review, 182, 72-89.

Christiano, L.J. and T. Fitzgerald (2003), 'The band pass filter', International Economic Review, 44, 435-465.

CPB, 2003, 'SAFE: A quarterly model of the Dutch economy for short-term analysis', CPB

Document 42, The Hague.

Hodrick, R. and E.C. Prescott (1997), 'Post-war U.S. business cycles: an empirical investigation', Journal of Money Credit and Banking, 29, 1-16.

Jacobs, J.P.A.M. (1998), Econometric Business Cycle Research, Kluwer Academic Publishers,

Boston/Dordrecht/London.

Jacobs, J.P.A.M., R.M. Salomons and E. Sterken (1997), 'The CCSO composite leading indicator of the Netherlands: construction, forecasts and comparison', CCSO Series No. 31, Center for Cyclical and Structural Research, Groningen.

Kranendonk, H.C. (1990), 'CPB-conjunctuurindicator', Working Paper No. 36, CPB,

Den Haag. (in Dutch). 
Kranendonk, H.C. and C.L. Jansen (1997), 'Using leading indicators in a model-based

forecast', CPB Report, 1997/3.

McGuckin, R., A. Ozyildirim and V. Zarnowitz (2003), 'A More Timely and Useful Index of leading Indicators', Economic program Working Paper \#03 - 01, The Conference Board, New York.

Lebrun, I. (1999), 'Le système d'indicateurs avancés du BfP', Un nouvel outil pour l'analyse conjuncturelle, Working Paper 2-99, Bureau fédéral du Plan, Brussel.

OECD (1987), 'OECD Leading indicators and business cycles in member countries 19601985', Sources and Methods, 39, Paris.

Ravn, O.M. and H. Uhlig (2002), 'On adjusting the HP-filter for the frequency of observations', Review of Economics and Statistics, 84, 371-376.

Reijer, A.H.J, den (2002), 'International business cycle indicators, measurement and forecasting', Research Memorandum WO no 689, De Nederlandsche Bank, Amsterdam.

Zarnowitz. V. and A. Ozyildirim (2002), 'Time series decomposition and measurement of business cycles, trends and growth cycles', NBER Working Paper 8736. 


\section{CESifo Working Paper Series}

(for full list see www.cesifo.de)

1132 David M. Newbery, Privatising Network Industries, February 2004

1133 Charles Yuji Horioka, The Stagnation of Household Consumption in Japan, February 2004

1134 Eiji Fujii, Exchange Rate Pass-Through in the Deflationary Japan: How Effective is the Yen's Depreciation for Fighting Deflation?, February 2004

1135 Mark M. Spiegel and Nobuyoshi Yamori, Determinants of Voluntary Bank Disclosure: Evidence from Japanese Shinkin Banks, Febrary 2004

1136 Robert Dekle and Kenneth Kletzer, Deposit Insurance, Regulatory Forbearance and Economic Growth: Implications for the Japanese Banking Crisis, February 2004

1137 Takatoshi Ito and Kimie Harada, Bank Fragility in Japan, 1995-2003, February 2004

1138 Kunio Okina and Shigenori Shiratsuka, Policy Duration Effect under Zero Interest Rates: An Application of Wavelet Analysis, February 2004

1139 Francine D. Blau and Lawrence M. Kahn, Do Cognitive Test Scores Explain Higher U.S. Wage Inequality?, February 2004

1140 Michael Rauscher, Economic Growth and Tax-Competing Leviathans, February 2004

1141 Ernst Fehr and Jean-Robert Tyran, Money Illusion and Coordination Failure, February 2004

1142 Ingo Vogelsang, Network Utilities in the U.S. - Sector Reforms without Privatization, March 2004

1143 Marc-Andreas Muendler, Estimating Production Functions When Productivity Change is Endogenous, March 2004

1144 Sascha O. Becker, Samuel Bentolila, Ana Fernandes, and Andrea Ichino, Job Insecurity and Children's Emancipation, March 2004

1145 Pascalis Raimondos-Møller and Alan D. Woodland, Non-Preferential Trading Clubs, March 2004

1146 Robert Fenge and Matthias Wrede, EU Regional Policy: Vertical Fiscal Externalities and Matching Grants, March 2004

1147 Chi-Yung Ng and John Whalley, Geographical Extension of Free Trade Zones as Trade Liberalization: A Numerical Simulation Approach, March 2004 
1148 Marc-Andreas Muendler, Trade, Technology, and Productivity: A Study of Brazilian Manufacturers, 1986-1998, March 2004

1149 Eugene Beaulieu, Vivek H. Dehejia, and Hazrat-Omar Zakhilwal, International Trade, Labour Turnover, and the Wage Premium: Testing the Bhagwati-Dehejia Hypothesis for Canada, March 2004

1150 Giorgio Brunello and Francesca Gambarotto, Agglomeration Effects on Employer-Provided Training: Evidence from the UK, March 2004

1151 S. Brock Blomberg, Gregory D. Hess, and Athanasios Orphanides, The Macroeconomic Consequences of Terrorism, March 2004

1152 Bodo Sturm and Joachim Weimann, Unilateral Emissions Abatement: An Experiment, March 2004

1153 Wolfgang Ochel, Welfare-to-Work Experiences with Specific Work-First Programmes in Selected Countries, March 2004

1154 Jan K. Brueckner and Eric Pels, European Airline Mergers, Alliance Consolidation, and Consumer Welfare, March 2004

1155 Aaron Tornell, Frank Westermann, and Lorenza Martínez, NAFTA and Mexico's Economic Performance, March 2004

1156 George Economides, Sarantis Kalyvitis, and Apostolis Philippopoulos, Do Foreign Aid Transfers Distort Incentives and Hurt Growth? Theory and Evidence from 75 Aid-recipient Countries, March 2004

1157 Robert Fenge and Volker Meier, Are Family Allowances and Fertility-related pensions Siamese Twins?, March 2004

1158 Bruno S. Frey, Simon Luechinger, and Alois Stutzer, Valuing Public Goods: The Life Satisfation Approach, March 2004

1159 Jerome L. Stein and Guay C. Lim, Asian Crises: Theory, Evidence, Warning-Signals, March 2004

1160 Romain Ranciere, Aaron Tornell, and Frank Westermann, Crises and Growth: A Re-Evaluation, March 2004

1161 Assaf Razin and Efraim Sadka, Transparency, Specialization and FDI, March 2004

1162 Ludger Woessmann, How Equal Are Educational Opportunities? Family Background and Student Achievement in Europe and the United States, March 2004

1163 B.M.S. van Praag and Barbara E. Baarsma, Using Happiness Surveys to Value Intangibles: The Case of Airport Noise, March 2004

1164 Aaron Tornell, Frank Westermann, and Lorenza Martínez, The Positive Link Between Financial Liberalization, Growth, and Crises, March 2004 
1165 Helge Berger and Carsten Hefeker, One Country, One Vote? Labor Market Structure and Voting Rights in the ECB, March 2004

1166 Clemens Fuest and Martin Kolmar, A Theory of User-Fee Competition, March 2004

1167 Friedrich Schneider and Robert Klinglmair, Shadow Economies around the World: What Do We Know?, April 2004

1168 Horst Raff and Nicolas Schmitt, Exclusive Dealing and Common Agency in International Markets, April 2004

1169 M. Hashem Pesaran and Allan Timmermann, Real Time Econometrics, April 2004

1170 Sean D. Barrett, Privatisation in Ireland, April 2004

1171 V. Anton Muscatelli, Patrizio Tirelli and Carmine Trecroci, Can Fiscal Policy Help Macroeconomic Stabilisation? Evidence from a New Keynesian Model with Liquidity Constraints, April 2004

1172 Bernd Huber and Marco Runkel, Tax Competition, Excludable Public Goods and User Charges, April 2004

1173 John McMillan and Pablo Zoido, How to Subvert Democracy: Montesinos in Peru, April 2004

1174 Theo Eicher and Jong Woo Kang, Trade, Foreign Direct Investment or Acquisition: Optimal Entry Modes for Multinationals, April 2004

1175 Chang Woon Nam and Doina Maria Radulescu, Types of Tax Concessions for Attracting Foreign Direct Investment in Free Economic Zones, April 2004

1176 M. Hashem Pesaran and Andreas Pick, Econometric Issues in the Analysis of Contagion, April 2004

1177 Steinar Holden and Fredrik Wulfsberg, Downward Nominal Wage Rigidity in Europe, April 2004

1178 Stefan Lachenmaier and Ludger Woessmann, Does Innovation Cause Exports? Evidence from Exogenous Innovation Impulses and Obstacles, April 2004

1179 Thiess Buettner and Johannes Rincke, Labor Market Effects of Economic Integration - The Impact of Re-Unification in German Border Regions, April 2004

1180 Marko Koethenbuerger, Leviathans, Federal Transfers, and the Cartelization Hypothesis, April 2004

1181 Michael Hoel, Tor Iversen, Tore Nilssen, and Jon Vislie, Genetic Testing and Repulsion from Chance, April 2004

1182 Paul De Grauwe and Gunther Schnabl, Exchange Rate Regimes and Macroeconomic Stability in Central and Eastern Europe, April 2004 
1183 Arjan M. Lejour and Ruud A. de Mooij, Turkish Delight - Does Turkey's accession to the EU bring economic benefits?, May 2004

1184 Anzelika Zaiceva, Implications of EU Accession for International Migration: An Assessment of Potential Migration Pressure, May 2004

1185 Udo Kreickemeier, Fair Wages and Human Capital Accumulation in a Global Economy, May 2004

1186 Jean-Pierre Ponssard, Rent Dissipation in Repeated Entry Games: Some New Results, May 2004

1187 Pablo Arocena, Privatisation Policy in Spain: Stuck Between Liberalisation and the Protection of Nationals' Interests, May 2004

1188 Günter Knieps, Privatisation of Network Industries in Germany: A Disaggregated Approach, May 2004

1189 Robert J. Gary-Bobo and Alain Trannoy, Efficient Tuition Fees, Examinations, and Subsidies, May 2004

1190 Saku Aura and Gregory D. Hess, What's in a Name?, May 2004

1191 Sjur Didrik Flåm and Yuri Ermoliev, Investment Uncertainty, and Production Games, May 2004

1192 Yin-Wong Cheung and Jude Yuen, The Suitability of a Greater China Currency Union, May 2004

1193 Inés Macho-Stadler and David Pérez-Castrillo, Optimal Enforcement Policy and Firms' Emissions and Compliance with Environmental Taxes, May 2004

1194 Paul De Grauwe and Marianna Grimaldi, Bubbles and Crashes in a Behavioural Finance Model, May 2004

1195 Michel Berne and Gérard Pogorel, Privatization Experiences in France, May 2004

1196 Andrea Galeotti and José Luis Moraga-González, A Model of Strategic Targeted Advertising, May 2004

1197 Hans Gersbach and Hans Haller, When Inefficiency Begets Efficiency, May 2004

1198 Saku Aura, Estate and Capital Gains Taxation: Efficiency and Political Economy Consideration, May 2004

1199 Sandra Waller and Jakob de Haan, Credibility and Transparency of Central Banks: New Results Based on Ifo's World Economicy Survey, May 2004

1200 Henk C. Kranendonk, Jan Bonenkamp, and Johan P. Verbruggen, A Leading Indicator for the Dutch Economy - Methodological and Empirical Revision of the CPB System, May 2004 